\title{
Correlation between Plasma Osteopontin and Alkaline Phosphatase in Type 2 Diabetes Mellitus Patients
}

\author{
Josua TH Sinambela, M.I. Diah Pramudianti, Dian Ariningrum \\ Department of Clinical Pathology, Faculty of Medicine, Sebelas Maret University/Dr. Moewardi Hospital Surakarta, Indonesia. E-mail: \\ josuasinambela@yahoo.com
}

\section{ABSTRACT}

\begin{abstract}
Diabetes Mellitus (DM) is a chronic disease caused by pancreas the inability to produce insulin or ineffectively insulin use. Fracture risk in type $2 \mathrm{DM}$ patients increases even though the bone density is normal. This study aimed to examine the correlation of osteopontin (OPN) and alkaline phosphatase (ALP) in type 2 DM patients. An observational analytical study was conducted in 73 type 2 DM patients in Dr. Moewardi Hospital, Surakarta from October to November 2018. The subjects were examined for blood pressure, fasting blood glucose, two hours postprandial blood glucose, HbA1c, OPN, and ALP levels. P-value $<0.05$ was statistically significant with a $95 \%$ confidence interval. Poorly controlled type $2 \mathrm{DM}$ had higher OPN levels than well-controlled ( $20.5 \pm 2.8$ vs. $14.8 \pm 3.1 \mathrm{ng} / \mathrm{mL}, \mathrm{p}<0.001)$. The ALP concentration was also higher in poorly controlled type $2 \mathrm{DM}$ patients $(79.9 \pm 31.7 \mathrm{vs} .61 .1 \pm 25 \mathrm{U} / \mathrm{L}, \mathrm{p}=0.003)$. The levels of OPN and ALP were significantly correlated in type 2 diabetes $(r=0.273 ; p=0.020)$ and in well-controlled patients $(r=0.353 ; p=0.047)$ but no correlation was found in poorly controlled type $2 \mathrm{DM}$ patients $(r=-0.073 ; p=0.652)$. In this study, a significant correlation was found between OPN and ALP in patients with type $2 \mathrm{DM}$ and well-controlled. Further study involving healthy controls and bone ALP measurement is needed.
\end{abstract}

Keywords: Type 2 diabetes mellitus, osteopontin, alkaline phosphatase

\section{INTRODUCTION}

Diabetes Mellitus (DM) is a chronic disease that occurs both when the pancreas cannot produce insulin (a hormone that regulates blood glucose) insufficient quantities and when the body ineffectively utilizes the insulin. Diabetes can lead to various complications in many parts of the body which increases the risk of premature death. Possible complications such as heart attack, stroke, kidney failure, loss of vision and nerve damage can occur. ${ }^{1}$

Epidemiological studies have shown an increase in the incidence and prevalence of type 2 DM worldwide and this increase is one of the global health threats. The World Health Organization has predicted an increase in the number of people with DM in Indonesia from 8.4 million in 2000 to around 21.3 million in 2030. The International Diabetes Federation (IDF) estimated an increase in people with DM in Indonesia from 9.1 million in 2014 to 14.1 million in 2035. ${ }^{2}$ Basic health research (RISKESDAS) 2013 demonstrated that prevalences of DM based on the doctors most common diagnosis were $2.1 \%$, $2.5 \%, 2.4 \%, 2.3 \%$ in Yogyakarta, Jakarta, North Sulawesi, and East Kalimantan respectively. ${ }^{3}$
Complicationsof DM consist of macrovascular and microvascular complications such as stroke, Coronary Artery Disease (CAD), neuropathy and peripheral vascular disease. Another interesting complication is that DM seems to affect bone health. Changes in bone metabolism in DM patients are related to bone strength, bone turnover and stem cell differentiation which result in changes in Bone Mineral Density (BMD) and bone structure. ${ }^{4}$ These changes are different between type $2 \mathrm{DM}$ and type 1 DM. Type 1 has a decrease in BMD whereas in type 2 BMD it is on the contrary.

The discrepancy that occurs between BMD and the risk of fracture is in line with the evidence in experimental animals that found a weakening of bone tissue in diabetic patients. This attenuation may be related to collagen replication and the formation of AGEs and AGEs (RAGE) receptors inducing a decrease in bone cell activity, bone turnover, and its formation. ${ }^{5}$ Hyperinsulinemia itself may be the reason for the increase in BMD. Insulin can interact with Insulin-like Growth Factor-1 (IGF-1) receptors found on the surface of the osteoblasts due to the similarity of its structure. Insulin-like growth factor-1 is known to have a strong positive correlation with 
BMD in both humans and experimental animals. Based on this, it is likely that hyperinsulinemia can trigger osteoblast division and differentiation. ${ }^{6.7}$

Osteopontin (OPN), also called as secreted phosphoprotein 1 (SPP 1), is an extracellular matrix protein that was first discovered in bone tissue. It consists of 314 amino acids with molecular weights varying between 44 and 75 kilo Dalton $(\mathrm{kDa})$. Osteopontin has an important role in inflammation by increasing the number of macrophages and $T$ cells; in bone biomineralization by modulating osteoclast function; in cancer by triggering migration of cells; in DM by increasing insulin resistance; in wound healing by increasing infiltration of macrophages and transforming secretion growth factor- $\beta$ (TGF- $\beta$ ); in nephrolithiasis, by preventing the formation and accumulation of calcium oxalate crystals. ${ }^{8.9}$ Osteopontin has an important role in the occurrence of this resistance by increasing the accumulation of macrophages in adipose tissue and triggering inflammation. ${ }^{10}$ Hyperglycemic conditions are also known to trigger the OPN genes expression in mesangial cells, but the mechanism is not yet known. ${ }^{11,12}$

Alkaline phosphatase is an enzyme secreted by osteoblasts as part of the mineral matrix formation and acts as one of the formation of markers in bone turnover. ${ }^{5}$ The role of ALP in mineralization occurs in the early stage of bone development through a complex mechanism. A study shows that ALP as an inflammatory mediator such as C-Reactive Protein (CRP) in poorly controlled type $2 \mathrm{DM}$ increases significantly compared to that of in healthy subjects. Increased ALP activity is a response to oxidative stress and possibly as a result of normal and stress cell turnover. ${ }^{13}$

This study aimed to analyze the correlation of plasma OPN and total ALP concentration in type 2 DM patients including well-controlled and poorly controlled.

\section{METHODS}

This was an observational analytical study with a cross-sectional approach performed in all type $2 \mathrm{DM}$ patients diagnosed by clinicians in the Internal Medicine Outpatients Clinic in the Endocrinology Sub-Department who underwent laboratory examinations at the Clinical Pathology Laboratory of the Dr. Moewardi Hospital Surakarta from October to November 2018. A total of 73 subjects met our inclusion criteria. Samples were taken from a venous blood vessel, divided into two including $5 \mathrm{~mL}$ of blood without anticoagulant to examine ALP levels, and $3 \mathrm{~mL}$ in EDTA for OPN examination. After the $\mathrm{HbA} 1 \mathrm{c}$ examination, EDTA samples were centrifuged within 10-15 minutes at 5,000-6,000 rpm. Blood plasma was taken and inserted into the aliquot. Blood samples without anticoagulants were centrifuged for 10-15 minutes at 5,000-6,000 rpm. The serum was taken and put into aliquots. Plasma and serum samples were stored in a refrigerator at $-80^{\circ} \mathrm{C}$ until analysis was performed.

Osteopontin levels were measured by quantitative sandwich Enzyme-Linked Immunosorbent Assay (Sandwich ELISA) from Elabscience. Alkaline phosphatase levels were measured by Advia 1800 chemistry analyzer with kinetic photometry. Levels of $\mathrm{HbA1c}$ were measured using ARKRAY ADAMS A1c Lite with reversed-phase cation exchange chromatography.

Type 2 DM patients, over 40 years old, and who agreed to participate in the study by signing an informed consent were included in our study.

Subjects with the history or suffering from liver and kidney diseases, bone abnormalities (rickettsia, bone deformities, osteomalacia), anemia, pregnancy, $\mathrm{Hb}$ variant abnormalities/ hemoglobinopathy (thalassemia) were excluded from the study.

Variable with a nominal scale such as sex was described as frequency and percentage. Continuous scale data such as age, OPN, ALP, HbAlc with a number of samples $>50$ were analyzed with Kolmogorov-Smirnov and presented in a table containing mean \pm SD if normally distributed and in the median form (minimum-maximum) if not normally distributed. A comparative test was conducted to assess the relation of OPN and ALP to glycemic control. The numerical comparative test of two unpaired groups used unpaired t-test if normally distributed and Mann-Whitney test if not normally distributed. The strength of the correlation between the two variables was analyzed with Pearson correlation test ${ }^{\circledR}$. Statistical analysis was processed by using a computer program, $p$-value $<0.05$ was considered as significant with a $95 \%$ confidence interval.

This study was approved by the Biomedical Research Ethics Commission at FK UNS/RSDM in Surakarta and patient approval with number $753 / \mathrm{XI} / \mathrm{HREC} / 2018$. Consent was willing to be the subject of research was obtained by first explaining briefly the background, objectives, benefits of the study as well as blood sampling techniques to the patients. The patients signed a statement willing to be the subject of research that had been provided. 


\section{RESULTS AND DISCUSSION}

The baseline characteristics of the study were presented in Table 1 consisting of 40(54.8\%) male and $33(45.2 \%)$ female patients. The median age of the overall patient was $61(42-75)$ years. Median duration of being diabetes was 8(5-19) years. Median Systolic Blood Pressure (SBP) was $120 \mathrm{mmHg}$ (100-160 mmHg) and Diastolic Blood Pressure (DBP) $80 \mathrm{mmHg}(67-100 \mathrm{mmHg})$. Fasting Blood Sugar (FBS) with a mean of $169.6 \pm 54.2 \mathrm{mg} / \mathrm{dL}$ and two hours postprandial of blood sugar (PP2BS) with a mean of $199.1 \pm 64.6 \mathrm{mg} / \mathrm{dL}$.

This comparative study involved 73 patients with type 2 DM, comprising 32(43.8\%) patients with good glycemic control ( $\mathrm{HbA} 1 \mathrm{c}<7 \%)$ the mean FBS of $145.1 \pm 35.8 \mathrm{mg} / \mathrm{dL}$, and the mean PP2BS of $163.9 \pm 34.6 \mathrm{mg} / \mathrm{dL}$ compared to $41(56.2 \%)$ patients with poor glycemic control $(\mathrm{HbA} 1 \mathrm{c} \geq 7 \%)$, a higher mean FBS level of $188.7 \pm 58.7 \mathrm{mg} / \mathrm{dL}$, and the mean PP2BS of $226.5 \pm 69.4 \mathrm{mg} / \mathrm{dL}$. The differences between FBS and PP2BS on glycemic control status were statistically significant $(p<0.001)$ (Table 2$)$.

Table 1. Baseline characteristics of the study subjects

\begin{tabular}{|c|c|c|c|}
\hline Variable & Amount (\%) & Mean \pm SD & Median (min-max) \\
\hline Age $(\text { years })^{a}$ & & & $61(42-75)$ \\
\hline \multicolumn{4}{|l|}{ Gender } \\
\hline Males & $40(54.8)$ & & \\
\hline Females & $33(45.2)$ & & \\
\hline Duration of DM (years) ${ }^{a}$ & & & $8(5-19)$ \\
\hline \multicolumn{4}{|l|}{ Blood Pressure } \\
\hline $\mathrm{SBP}(\mathrm{mmHg})^{\mathrm{a}}$ & & & $120(100-160)$ \\
\hline $\mathrm{DBP}(\mathrm{mmHg})^{\mathrm{a}}$ & & & $80(67-100)$ \\
\hline FBS $(\mathrm{mg} / \mathrm{dL})^{\mathrm{b}}$ & & $169.6 \pm 54.2$ & \\
\hline PP2BS (mg/dL) & & $199.1 \pm 64.6$ & \\
\hline
\end{tabular}

Description: SD: Standard Deviation; Min: lowest value; Max: highest value; $\mathrm{mmHg}$ : Millimeters of Mercury; $\mathrm{mg} / \mathrm{dL}$ : Milligrams per Deciliter; SBP: Systolic Blood Pressure; DBP: Diastolic Blood Pressure; FBS: Fasting Blood Glucose; PP2BS: 2 hours postprandial blood sugar

a : abnormal data distribution [median (min-max)]

${ }^{\mathrm{b}}$ : normal data distribution (mean $\pm \mathrm{SD}$ )

Table 2. Comparison of baseline characteristics based on glycemic control status

\begin{tabular}{cccc}
\hline Variable & $\begin{array}{c}\text { Type 2 DM } \\
\text { Well-Controlled } \\
\text { HbA1c }<7 \%(n=32)\end{array}$ & $\begin{array}{c}\text { Type 2 DM } \\
\text { Poorly-Controlled } \\
\text { HbA1c } \geq 7 \%(n=41)\end{array}$ & p \\
\hline Age (year) & $62(42-69)$ & $60(44-75)$ & 0.344 \\
Gender & & & \\
Males & $20(27.4 \%)$ & $20(27.4 \%)$ & - \\
Females & $12(16.4 \%)$ & $21(28.8 \%)$ & - \\
Duration of DM (years) ${ }^{a}$ & $8(5-16)$ & $8(5-19)$ & 0.305 \\
Blood Pressure & & & \\
SBP (mmHg) & $120(100-160)$ & $130(100-150)$ & 0.177 \\
DBP (mmHg) & $80(67-100)$ & $80(69-95)$ & 0.995 \\
FBS (mg/dL) & $145.1 \pm 35.8$ & $188.7 \pm 58.7$ & $<0.001^{*}$ \\
PP2BS (mg/dL) & $163.9 \pm 34.6$ & $226.5 \pm 69.4$ & $<0.001^{*}$ \\
\hline
\end{tabular}

Description: DM: Diabetes Mellitus; mmHg: Millimeters of Mercury; mg/dL: Milligrams per Deciliter; SBP: Systolic Blood Pressure; DBP: Diastolic Blood Pressure; FBS: Fasting Blood Sugar; PP2BS: 2 hours postprandial blood sugar

* $\mathrm{p}<0.05$ was significant;

${ }^{a}$ : abnormal data distribution [median (min-max)], different test with Mann-Whitney

${ }^{\mathrm{b}}$ : normal data distribution (mean $\pm \mathrm{SD}$ ), different test with independent t-test 
The OPN level was also significantly different $(p<0.001)$ between the well-controlled (mean of $14.8 \pm 3.1 \mathrm{ng} / \mathrm{mL}$ ) and poorly controlled (mean of $20.5 \pm 2.8 \mathrm{ng} / \mathrm{mL}$ ) groups. Alkaline phosphatase level was significantly higher in the poorly controlled group $(78.9 \pm 31.7 \mathrm{U} / \mathrm{L})$ than that of in well-controlled group $(61.1 \pm 25.0 \mathrm{U} / \mathrm{L})$. The well-controlled group had a lower $\mathrm{HbAlc}$ level than the poorly controlled group, i.e. $6.4 \%(5.3-6.9 \%)$ and $8.6 \%(7.0-12.8 \%)$ respectively (Table 3, Figure 1,2).

Table 3. Comparison of research variables based on glycemic control status

\begin{tabular}{lcccc}
\hline Variable & Total & $\begin{array}{c}\text { Type 2 DM } \\
\text { Well-Controlled } \\
\text { HbAlc }<7 \%(n=32)\end{array}$ & $\begin{array}{c}\text { Type 2 DM } \\
\text { Poorly-Controlled } \\
\text { HbAlc } \geq 7 \%(n=41)\end{array}$ & P \\
\hline OPN $(\mathrm{ng} / \mathrm{mL})^{\mathrm{b}}$ & $18.0 \pm 14.1$ & $14.8 \pm 3.1$ & $20.5 \pm 2.8$ & $<0.001^{*}$ \\
$\mathrm{ALP}(\mathrm{U} / \mathrm{L})^{\mathrm{b}}$ & $71.1 \pm 30.1$ & $61.1 \pm 25.0$ & $78.9 \pm 31.7$ & $0.003^{*}$ \\
$\mathrm{HbA1c}(\%)^{\mathrm{a}}$ & $7.3(5.3-12.8)$ & $6.4(5.3-6.9)$ & $8.6(7.0-12.8)$ & $<0.001^{*}$ \\
\hline
\end{tabular}

Description: DM: Diabetes Mellitus; HbAlc: hemoglobin adult 1 c; ng/mL: nanogram per milliliter; U/L: units per liter; OPN: osteopontin; ALP: alkaline phosphatase

${ }^{*} \mathrm{p}<0.05$ was significant

a : abnormal data distribution [median (min-max)], different test with Mann-Whitney

${ }^{\mathrm{b}}:$ normal data distribution (mean $\pm \mathrm{SD}$ ), different test with independent $\mathrm{t}$-test

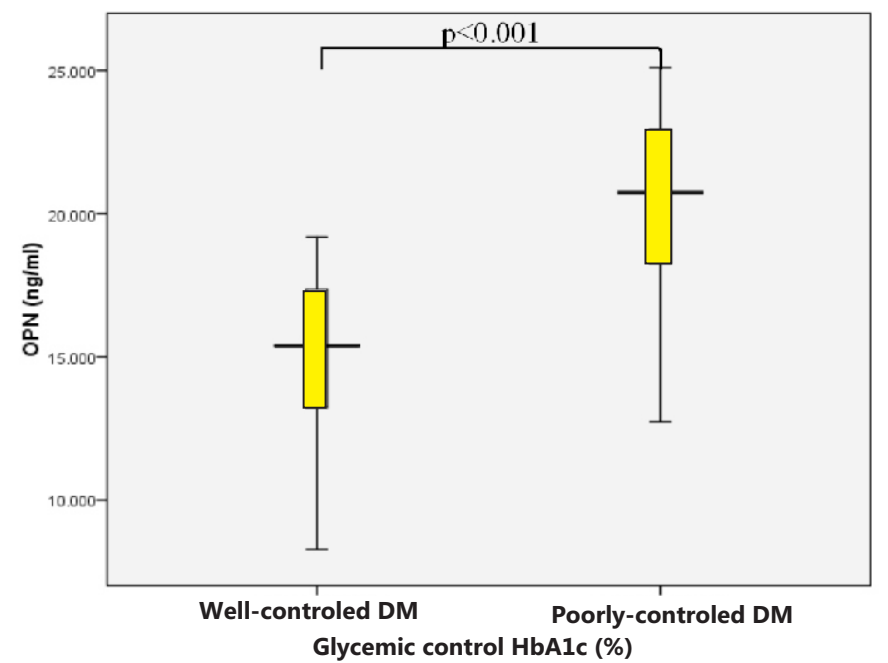

Figure 1. Box plot OPN based on glycemic control status showed a significant difference with $p<0.001$

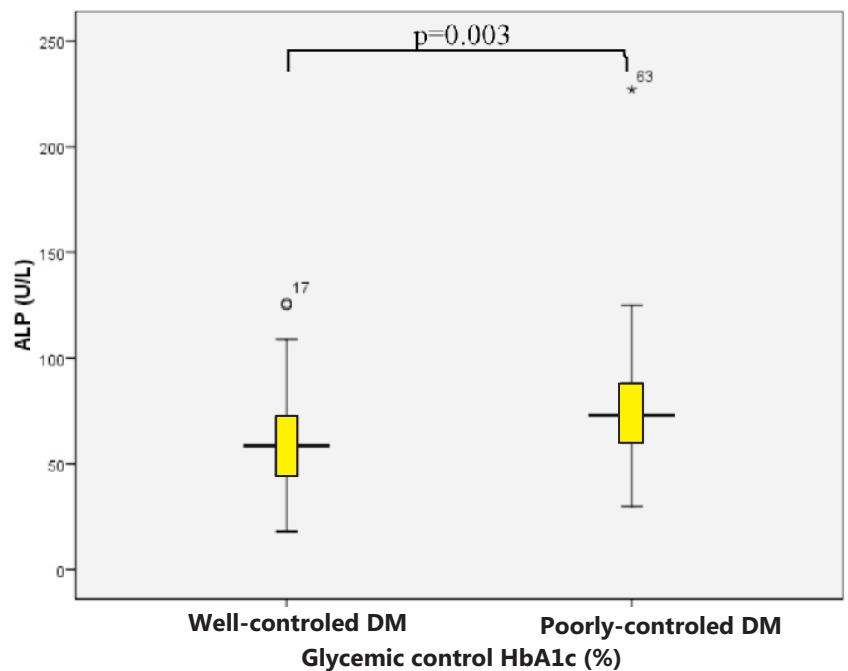

Figure 2. Box plot ALP based on glycemic control status showed a significant difference with $p=0.003$ 
Table 4. Correlation of OPN with ALP in type 2 DM patients

\begin{tabular}{cccccccc}
\hline \multirow{2}{*}{ Variable } & \multicolumn{2}{c}{ Total } & & \multicolumn{4}{c}{ Type 2 DM $^{*}$} \\
\cline { 2 - 7 } & & & \multicolumn{2}{c}{ Well-Controlled $^{\mathbf{c}}$} & \multicolumn{2}{c}{ Poorly-Controlled $^{\mathbf{c}}$} \\
\cline { 2 - 7 } & $\mathrm{r}$ & $\mathrm{p}$ & $\mathrm{r}$ & $\mathrm{p}$ & $\mathrm{r}$ & $\mathrm{p}$ \\
\hline OPN and ALP & 0.273 & $0.020^{*}$ & 0.353 & $0.047^{*}$ & -0.073 & 0.652 \\
\hline
\end{tabular}

Description: DM: Diabetes Mellitus; OPN: Osteopontin; ALP: Alkaline Phosphatase

* Significant correlation, $\mathrm{p}<0.05$

${ }^{\mathrm{c}}$ : Pearson correlation test
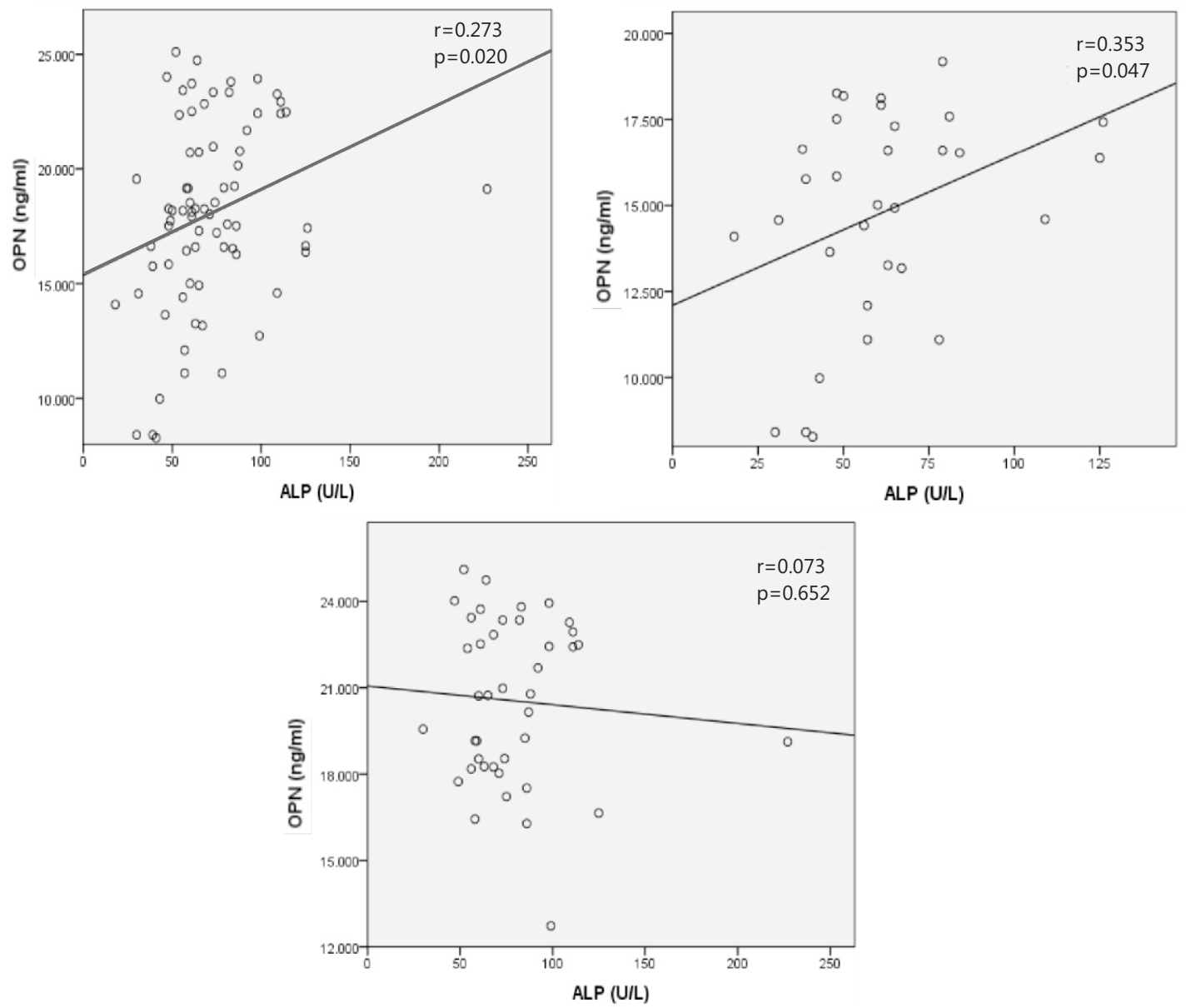

Figure 3. The correlation of OPN and ALP in all type 2 DM patients (A), the well-controlled type 2 DM (B), and poorly-controlled type $2 \mathrm{DM}(\mathrm{C})$

The correlation analysis showed a significant positive correlation with a weak strength between OPN and ALP levels in all type 2 DM patients $(r=0.273 ; p=0.020)$ and in well-controlled group $(r=0.353 ; p=0.047)$, but no correlation was found in poorly controlled type 2 DM patients $(r=-0.073$; $\mathrm{p}=0.652)$ (Table 4, Figure 3).

The baseline characteristics of our study subjects revealed asignificant differences in FBS and PP2BS levels between the well and poorly controlled groups of type $2 \mathrm{DM}$, which was line with the study of Sultan et al. ${ }^{14}$ reporting that the FBS levels of both well-and poorly-controlled DM patient were significantly higher than those of normal control $(98.1 \pm 73.57$ vs. $239.64 \pm 97.78$ vs. $83 \pm 7.6 \mathrm{mg} / \mathrm{dL}$, respectively, $\mathrm{p}<0.001)$.

The comparison of the research variables showed significant differences in the levels of OPN, ALP, and $\mathrm{HbA} 1 \mathrm{c}$ between well and poorly controlled type 2 DM patients. In a post menopausal study by Fodor et $a l^{15}$ on 214 subjects, there were significant differences of OPN levels in a healthy subject, 
osteopenia and osteoporosis [8.60(5.20-12.63) vs. $9.00(5.70-16.87)$ vs. $13.18(10.50-17.04) \quad \mathrm{ng} / \mathrm{mL}$ respectively, $p=0.0003]$. The OPN level cut-off point used in their study to determine lumbar spine and femoral osteoporosis was 9.47 and $10.15 \mu \mathrm{g} / \mathrm{L}$, however, this cut-off point could not be generalized because the OPN level was dependent on the examination method. Chang et al. found that levels of $14.7 \mathrm{ng} / \mathrm{mL}$ had a 2.97 fold risk of osteoporosis. ${ }^{16}$

A study by Gordin et al. ${ }^{17}$ on 2145 patients also demonstrated significant difference between 4 group of patients based on the baseline quartile OPN level (group $1=0.5-9.0$; group $2=9.0-14.0$; group $3=14.0-20.6$; group $4=20.6-208.9 \mu \mathrm{g} / \mathrm{L}$ ) with mean OPN levels (group $1=6.3 \pm 0.1$; group $2=11.4 \pm 0.1$; group $3=16.9 \pm 0,1 ;$ group $4=31.4 \pm 0.6 \mu \mathrm{g} / \mathrm{L}$, $p<0.001)$. There were significant differences between $\mathrm{HbA1}$ c levels with levels (group $1=8.4 \pm 0.1$; group $2=8.4 \pm 0.1 ;$ group $3=8.4 \pm 0.1$; group $4=8.6 \pm 0.1 \%, p=0.04)$. Barchetta et al. ${ }^{18}$ also showed significant differences in OPN levels between type 1 DM patients compared with controls [13.6 (1.4-62.9) vs. $5.7(0.2-76.8) \mu \mathrm{g} / \mathrm{L}$, respectively, $\mathrm{P}=0.009$ ].

Research by Deepika et al..$^{13}$ on 390 type 2 DM patients showed significant differences in ALP levels between the control group with well-controlled DM $(142.17 \pm 16.48$ vs. $145 \pm 23.91 \mathrm{IU} / \mathrm{L}, \mathrm{p}<0.05)$ and the control group with DM poorly-controlled $(142.17 \pm 16.48$ vs. $147.79 \pm 28.95 \mathrm{IU} / \mathrm{L}, \mathrm{p}<0.0001)$. Sultan et al. ${ }^{14}$ study also showed similar findings to our study which showed significant differences in ALP concentration between normal controls and well-controlled type 2 DM patients $(144 \pm 22.54$ vs. $177 \pm 39.88 \mathrm{IU} / \mathrm{L}, \mathrm{p}<0.05)$ and between normal controls and poorly-controlled type $2 \mathrm{DM}$ patients $(144 \pm 22.54$ vs. $287 \pm 41.4 \mathrm{IU} / \mathrm{L}, \mathrm{p}<0.001)$, meanwhile our study showed that ALP level in poorly controlled was higher than in well-controlled type $2 \mathrm{DM}$ patients (78.9 \pm 31.7 vs. $61.1 \pm 25.0 \mathrm{IU} / \mathrm{L}, \mathrm{p}=0.003$, respectively). Increased ALP level could be caused by prolonged exposure to parathyroid hormones which eventually resulted in increased osteoblastic activity. ${ }^{4}$ In type 2 DM the HbAlc level was significantly different between normal controls and well-controlled $(5.1 \pm 0.35$ vs. $5.9 \pm 0.8 \%, p<0.001)$ as well as between normal controls and poorly-controlled $(5.1 \pm 0.35$ vs. $9.05 \pm 3.29 \%, p<0.001)$.

In this study, a bivariate analysis which assessed the correlation of OPN and ALP levels in well- and poorly-controlled showed a significant positive correlation in all type $2 \mathrm{DM}$ patients $(r=0.273$; $p=0.020$ ). This finding was in accordance with
Barchetta et al. ${ }^{18}$ study which found a significant correlation between OPN and ALP levels in DM patients $(r=0.27 ; p=0.04)$ and stated that the increase in OPN level was independently associated with type $1 \mathrm{DM}$ and impaired metabolic profiles patients. Osteopontin may have a role in predicting macro and microvascular complications in DM patients. Several other studies have suggested that OPN was the main key in inflammation of adipose tissue and insulin resistance with serum levels and expression of some proinflammatory cytokines such as IL6, TNFa, MCP-1, and iNOS significantly decreased in experimental animals with omitted OPN genes. This study reported that OPN deficiency resulted in reduced adipose tissue inflammation and increased insulin sensitivity. ${ }^{10,19}$

A study by Deepika et al. ${ }^{13}$ on serum ALP and high sensitivity C-reactive protein in type 2 DM patients assessing the risk of cardiovascular disorders showed a significant correlation between ALP levels and HbA1c $(r=0.84 ; p<0.0001)$. Increased ALP activity could occur in response to oxidative stress as well as due to normal cell turnover and cellular stress. Alkaline phosphatase may be used as a marker of insulin resistance syndrome in the pathogens of $\mathrm{DM}^{20}$

The bivariate analysis of the levels of OPN and ALP based on glycemic control (well-controlled and poorly-controlled) showed a significant correlation in well-controlled type 2 DM patients $(r=0.353$; $p=0.047)$ but not inpoorly-controlled one $(r=-0.073$; $\mathrm{p}=0.652$ ).

The limitations of this study included the use of a cross-sectional study design so that it could not as certain the causal relation between OPN, ALP and other variables with the occurrence of osteoporosis complications in type $2 \mathrm{DM}$ patients and the absence of healthy control causing an inability to assess OPN and ALP levels of healthy subjects. Measurement of total ALP level may also affect the assessment of ALP activity that occurred in type 2 DM patients. Thus, further study using healthy control and the measurement of bone ALP levels (BAP) is needed to strengthen our findings.

\section{CONCLUSION AND SUGGESTION}

In conclusion, there was a significant positive correlation with the weak strength between total OPN and ALP levels in all and well-controlled type 2 DM patients but there was no correlation between OPN and ALP levels in poorly controlled type 2 DM patients. Based on this study, it is necessary to 
conduct further research to determine the correlation between OPN and ALP in type 2 DM patients, using more specific ALP isoenzymes such as BAP and using different research designs, including healthy controls and with a larger number of samples.

\section{REFERENCES}

1. World Health Organization (WHO). Global report on diabetes. Geneva, WHO Press, 2016; 6-11.

2. Perkumpulan Endokrinologi Indonesia (PERKENI). Konsensus pengelolaan dan pencegahan diabetes melitus tipe 2 di Indonesia.PB PERKENI, 2015; 1-11.

3. Riset Kesehatan Dasar (RISKESDAS). Balai penelitian dan pengembangan kesehatan kementerian kesehatan RI. Jakarta, RISKESDAS, 2013; 87-90.

4. Botolin S, Mccabe L. Bone loss and increased bone adiposity in spontaneous and pharmacologically induced diabetic mice. Endocrinology, 2007; 148: 198-205.

5. Vestergaard P. Diabetes and bone. J Diabetes Metab. 2011;1-7.

6. Langlois JA, Rosen CJ, Visser M, Hannan MT, Harris T, et al. Association between insulin-like growth factor I and bone mineral density in older women and men: the Framingham Heart Study, J Clin Endocrinol Metab. 1998; 83: 4257-4262.

7. Zhou Z, Immel D, Xi C, Bierhaus A, Feng $X$, Mei $L$, Nawroth $P$, et al. Regulation of osteoclast function and bone mass by RAGE. J Exp Med, 2006; 203: 1067-1080.

8. Kahles F, Findelsen HM, Bruemmer D. Osteopontin: A novel regulator at the crossroads of inflammation, obesity, and diabetes. J Molmet, 2014; 3: 384-393.

9. Icer MA, Karadag MG. The multiple functions and mechanisms of osteopontin. J Clinbiochem, 2018; 1-18.

10. Nomiyama T, Perez TD, Ogawa D, Gizard F, Zhao Y, Heywood EB, Jones KL, et al. Osteopontin mediates obesity-induced adipose tissue macrophage infiltration and insulin resistance in mice. The Journal of Clinical Investigation, 2007; 10:2877-2888.

11. Sodhi CP, Phadke SA, Battle D, Sahai A. Hypoxia and high glucose cause exaggerated mesangial cell growth and collagen synthesis: Role of osteopontin.
American Journal of Physiology-Renal Physiology, 2001; 280(4): F667-F674.

12. Sun J, Xu Y, Deng H, Sun S, Dai Z, Sun Y. Involvement of osteopontin upregulation on mesangial cell growth and collagen synthesis induced by intermittent high glucose. Journal of Cellular Biochemistry, 2010; 109(6): 1210-1221.

13. Deepika G, Veeraiah N, Naved S, Ramana MV. Serum alkaline phosphatase and high sensitivity $\mathrm{C}$-reactive protein in type II diabetes mellitus: A risk of cardiovascular disease in south Indian population. Int J Res Med Sci. 2016; 4(4): 1107-1114.

14. Sultan E, Taha I, Saber LM. Altered bone metabolic markers in type 2 diabetes mellitus: Impact of glycemic control. J T U Med Sc, 2008; 3(2): 104-116.

15. Fodor D, Bondor C, Albu A, Simon S, Craciun A, Muntean $\mathrm{L}$. The value of osteopontin in the assessment of bone mineral density status in postmenopausal women. J Investig Med, 2013; 61: 15-21.

16. Chang IC, Chiang TI, Yeh KT, Lee H, Cheng YW. Increased serum osteopontin is a risk factor for osteoporosis in menopausal women. Osteoporos, 2010; 21(8): 1401-9.

17. Gordin D, Forsblom C, Panduru NM, Thomas MC, Bjerre $\mathrm{M}$, Paavonen AS, Tolonen $\mathrm{N}$, et al. Osteopontin in a strong predictor of incipient diabetic nephropathy, cardiovascular disease, and all-cause mortality in patients with type 1 diabetes. Diabetes Care, 2014; 1-8.

18. Barchetta L, Alessandri C, Bertoccini L, Cimini FA, Taverniti L, Di Franco M, Fraioli $A$, et al. Increased circulating osteopontin levels in adult patients with type 1 diabetes mellitus and association with dysmetabolic profile. Eur J Endocrinol, 2016; 174: 187-192.

19. Kiefer FW, Zeyda M, Todoric J, Huber J, Geyeregger R, Weichhart T, Aszmann $\mathrm{O}$, et al. Osteopontin expression in human and murine obesity: Extensive local up-regulation in adipose tissue but minimal systemic alterations. Endocrinology, 2008; 149: 1350-1357.

20. Amanullah $S$, Jarari A, Govindan M. Association of hsCRP with diabetic and non-diabetic individuals. Jordan J Biol Sci, 2010; 3(1): 7-12. 